\title{
Influence of nitrogen on the production characteristics of ruzi grass
}

\author{
Karina Batista*, Alessandra Aparecida Giacomini, Luciana Gerdes, Waldssimiler Teixeira de \\ Mattos, Maria Tereza Colozza and Ivani Pozar Otsuk
}

Instituto de Zootecnia, Agência Paulista de Tecnologia dos Agronegócios, Nova Odessa, Brazil.

Accepted 13 January, 2014

\begin{abstract}
Understanding the action of the nitrogen $(\mathrm{N})$ in grasses can aid in pasture management and increase the efficiency of this nutrient. The objective of this study was to determine the influence of $\mathrm{N}$ rates and of the available $\mathbf{N}$ from the previous crop on Brachiaria ruziziensis cv. Comum. The experiment was conducted in a greenhouse. The treatments were arranged in a $2 \times 4$ factorial design and were distributed according to a fully randomized block design with four replications. Two $\mathrm{N}$ rates $(0$ and 15 $\mathrm{mg} \mathrm{dm}$ ) were applied at grass planting and four $\mathbf{N}$ rates were applied as topdressing after the first cutting $\left(0,15,30\right.$ and $\left.45 \mathrm{mg} \mathrm{dm}^{-3}\right)$. The grass was cut twice above-ground. The comparison between $\mathrm{N}$ rates applied at planting was made using $F$ test, and the degrees of freedom of the $\mathrm{N}$ rates applied as topdressing were broken down into orthogonal polynomials. The $\mathrm{N}$ rate of $15 \mathrm{mg} \mathrm{dm}^{-3}$ applied at planting the ruzi grass promoted increases in the numbers of leaves and shoot dry matter production. During the second growth, $N$ rates $\left(15,30\right.$ and $\left.45 \mathrm{mg} \mathrm{dm}^{-3}\right)$ applied as topdressing increased the number of leaves and the shoot dry matter production. The available $\mathbf{N}$ from the previous crop (soybean) was sufficient for the initial tillering of the ruzi grass. This study showed that the correct management of $\mathbf{N}$ fertilization is necessary for ruzi grass when grown after a previous crop (soybean).
\end{abstract}

Key words: Available nitrogen, forage plants, management of nitrogen, residual nitrogen.

\section{INTRODUCTION}

The use of soybeans as a supplier of nitrogen $(\mathrm{N})$ to succeeding crops in direct planting in straw is widely discussed because legumes in general are able to fix from 11 to $336 \mathrm{~kg} \mathrm{ha}^{-1}$ of $\mathrm{N}$ per year (Havlin et al., 1999). By taking advantage of the available $\mathrm{N}$ from the previous crop (soybean), one method has been developed where grasses, especially Brachiaria ruziziensis cv. Comum (ruzi grass), are sown between rows of the second-crop corn so as to provide nutrients to the corn. Thus, the fertilization prioritizes the second-crop corn without considering that the limiting factor for the growth of herbage species is often the level of available $\mathrm{N}$ (Bland, 1968).
Ruzi grass has good drought tolerance. It requires soils with high fertility, such as Oxisols, and will tolerate acidic soils. It suppresses weeds and is useful for erosion control in areas where it grows well, but needs good drainage (it does not tolerate flooding). Finally, it responds well to nitrogen, either inorganic or from legumes (Cook et al., 2005).

Nitrogen is necessary for rapid growth of forage, and is an essential component of plant proteins. Since the amount of available $\mathrm{N}$ from the soil is typically less than the plants need, $\mathrm{N}$ fertilizer can be effectively used to increase forage productivity in pastures, as needed (Hancock et al., 2011). Nitrogen utilization efficiency can 
be 9 to $28 \mathrm{~kg}$ of dry matter per $1 \mathrm{~kg}$ of $\mathrm{N}$ applied. After $\mathrm{N}$ fertilizer is applied, $\mathrm{N}$ is rapidly absorbed into plants and growth is stimulated via improvement of root systems and photosynthetic activity. Responses of grassland to nitrogen vary according to several factors, such as type of $\mathrm{N}$ applied, application rate and timing (Sun et al., 2008).

Understanding the action of the $\mathrm{N}$ in the soil and grasses can aid in pasture management and increase the efficiency of this nutrient, especially knowing that the reduction of $\mathrm{N}$ availability is a major cause of tropical pasture degradation (Cao et al., 2012).

We hypothesize that the $\mathrm{N}$ doses usually applied at planting and in topdressing of second-crop corn could be also effective on $B$. ruziziensis cv. Comum. We tested this hypothesis under controlled conditions. The objective of this study was to determine the influence (i) of $\mathrm{N}$ rates applied at planting $\left(15 \mathrm{mg} \mathrm{dm}^{-3}\right)$ and in topdressing $(0$, 15,30 and $45 \mathrm{mg} \mathrm{dm}^{-3}$ ) of second-crop corn and (ii) of the available $\mathrm{N}$ from the previous crop (soybean) on the productive characteristics of $B$. ruziziensis cv. Comum.

\section{MATERIALS AND METHODS}

This study was carried out in a glass greenhouse under controlled conditions to avoid interferences of other nutrients (e.g., transfer of nutrients from other areas via animal manure) and ensure an adequate water supply and ambient temperature for normal plant growth.

The experiment was carried out in the summer of 2011 with soil from an area cultivated with soybean-second-crop corn rotation under a tillage system during 10 years, located in the municipality of Itapetininga ( $23^{\circ} 35^{\prime} 08^{\prime \prime}$; ; $\left.48^{\circ} 02^{\prime} 50^{\prime \prime W}\right)$, São Paulo State, Brazil. The soil is an Oxisol (dystrophic red Latosol). The soil was collected immediately after the soybean harvest and before planting the second-crop corn, at a depth of 0 to $20 \mathrm{~cm}$. The soil was dried, sieved, weighed and then placed in ceramic pots with capacity of $3.6 \mathrm{dm}^{3}$.

The chemical soil analysis showed the following results: $\mathrm{pH}$ in $\mathrm{CaCl}_{2}=5.8$; organic matter content $=38.0 \mathrm{mg} \mathrm{dm}{ }^{-3} ; \mathrm{P}$ (resin) $=132.0$ $\mathrm{mg} \mathrm{dm}{ }^{-3} ; \mathrm{K}($ resin $)=4.9 \mathrm{mmol}_{\mathrm{c}} \mathrm{dm}^{-3} ; \mathrm{Ca}($ resin $)=60.0 \mathrm{mmol}_{\mathrm{c}} \mathrm{dm}^{-3}, \mathrm{Mg}$ (resin) $=16.0 \mathrm{mmol}_{\mathrm{c}} \mathrm{dm}^{-3} ; \mathrm{Al}=0 \mathrm{mmol}_{\mathrm{c}} \mathrm{dm}^{-3} ; \mathrm{H}+\mathrm{Al}=31.0 \mathrm{mmol}_{\mathrm{c}} \mathrm{dm}^{-3}$; $\mathrm{SO}_{4}=6.0 \mathrm{mg} \mathrm{dm}^{-3}$; base saturation $(\mathrm{BS})=80.9 \mathrm{mmol}_{\mathrm{C}} \mathrm{dm}^{-3}$; cation exchange capacity $(C E C)=112.0 \mathrm{mmol}_{\mathrm{c}} \mathrm{dm}^{-3} ; \mathrm{V}=72.0 \% ; \mathrm{B}=0.19 \mathrm{mg}$ $\mathrm{dm}^{-3} ; \mathrm{Cu}=3.4 \mathrm{mg} \mathrm{dm}{ }^{-3} ; \mathrm{Fe}=15 \mathrm{mg} \mathrm{dm}^{-3} ; \mathrm{Mn}=3.0 \mathrm{mg} \mathrm{dm}^{-3}$ and $\mathrm{Zn}=$ $3.0 \mathrm{mg} \mathrm{dm}^{-3}$. These results showed that correction for soil acidity and fertilization with macro- and micronutrients was not necessary before sowing the grass (Werner, 1986).

Based on the observations of Batista et al. (2011), the treatments were arranged in a $2 \times 4$ factorial design, where two $\mathrm{N}$ rates $(0$ and $15 \mathrm{mg} \mathrm{dm}^{-3}$ ) were applied at planting the ruzi grass, and four $\mathrm{N}$ rates $\left(0,15,30\right.$ and $\left.45 \mathrm{mg} \mathrm{dm}^{-3}\right)$ were applied as topdressing after the first cutting. These $\mathrm{N}$ rates corresponded to those generally used for supplying $\mathrm{N}$ at planting and topping of second-crop corn in Brazil. Therefore, the following combinations were constituted: 0,0 ; 0,$15 ; 0,30 ; 0,45 ; 15,0 ; 15,15 ; 15,30$ and $15,45 \mathrm{mg} \mathrm{dm}^{-3}$. These combinations were distributed in a greenhouse in a fully randomized block design with four replications.

Five plants of Ruzi grass were grown per pot. On the day of sowing, initial $\mathrm{N}$ treatment of $15 \mathrm{mg} \mathrm{dm}^{-3}$ was applied in the form of an ammonium nitrate solution. The treatments without initial $\mathrm{N}$ received only distilled water.

At 19 days after the germination of the ruzi grass, the counting of leaves and tillers started. These counts were performed every seven days. The tillers were counted as soon as they presented a fully expanded leaf with a visible ligule, while the new leaves were also counted when they presented a visible ligule. The tillers were marked with plastic-coated wires, and inert ink was used for identification of the leaves.

At 39 days after the germination, the first cutting was performed, after which topdressing fertilization was applied to provide $40 \mathrm{mg}$ $\mathrm{dm}^{-3}$ of $\mathrm{P}_{2} \mathrm{O}_{5}$ in the form of potassium dihydrogen phosphate $\left(\mathrm{KH}_{2} \mathrm{PO}_{4}\right), 83 \mathrm{mg} \mathrm{dm}$ of $\mathrm{K}_{2} \mathrm{O}$, with $384 \mathrm{mg} \mathrm{dm}^{-3}$ in the form of $\mathrm{KH}_{2} \mathrm{PO}_{4}$ and $186.3 \mathrm{mg} \mathrm{dm}^{-3}$ in the form of potassium chloride $(\mathrm{KCl})$. A supply of potassium was necessary due to the appearance of potassium deficiency symptoms during the first growth, and phosphorus was provided to avoid limiting the response of the plants to the $\mathrm{N}$ doses. On the day following the cutting, $\mathrm{N}$ rates of 0 , 15,30 and $45 \mathrm{mg} \mathrm{dm}^{-3}$ were applied as topdressing in the form of ammonium nitrate to provide the planned $\mathrm{N}$.

Approximately eight days after the first cutting, chlorosis was observed in young leaves, accompanied by narrow dark green bands. As a result of these observations, $6 \mathrm{mg} \mathrm{dm}^{-3}$ of manganese was applied as manganese sulphate monohydrate $\left(\mathrm{MnSO}_{4} \cdot \mathrm{H}_{2} \mathrm{O}\right)$, and $15 \mathrm{mg} \mathrm{dm}^{-3}$ of sulphur was applied in the form of potassium sulphate $\left(\mathrm{K}_{2} \mathrm{SO}_{4}\right)$.

The second cutting occurred 27 days after the first, and the counting of the tillers and leaves was resumed eight days after the first cutting. Thus, the first growth was 39 days after germination and the second growth was 27 days after the first cutting.

After each cutting, each shoot was separated into: (a) Two newly expanded leaves; (b) Emerging leaves; (c) Mature leaves and (d) Stem + sheath. All these materials collected were dried in a forced air oven at $65^{\circ} \mathrm{C}$ until a constant weight was achieved.

The production of the total dry mass in the shoots was determined by the sum of the dry mass of the newly expanded leaves, emerging leaves, mature leaves and stem + sheaths. The leaf/stem ratio was determined using the dry mass production data of the leaf and stem fractions.

The comparison between $\mathrm{N}$ rates applied at planting was done using $\mathrm{F}$ test, and the degrees of freedom of the $\mathrm{N}$ rates applied as topdressing were broken down into orthogonal polynomials.

\section{RESULTS AND DISCUSSION}

\section{Tillering of ruzi grass}

The available $\mathrm{N}$ from the previous crop (soybean) was sufficient for the initial tillering of ruzi grass because in the first growth of the ruzi grass, the number of tillers did not differ between the $\mathrm{N}$ rates applied at planting (Table 1).

This result demonstrated that the available $\mathrm{N}$ from the previous crop (soybean) permitted the partial substitution of the $\mathrm{N}$ fertilizer. Legumes in general create very good conditions for subsequent crops, the main reason being the large amount of organic matter ploughed in Sarunaite et al. (2006). Thus, it is necessary to adapt the available $\mathrm{N}$ from the soybeans and the $\mathrm{N}$ from the fertilizer, according to the demand of the grass (Halvorson et al., 1999). In other words it is necessary to take care of adequate supply of $\mathrm{N}$ to the grass ruziziensis.

The number of tillers in the second growth of the Ruzi grass indicated that when the $\mathrm{N}$ was deficient, the development of the tillers was inhibited, but when the supply of $\mathrm{N}$ to the plants grown individually was increased, 
Table 1. Number of tillers and leaves, total dry mass of shoots and leaf/stem ratio of ruzi grass as a function of nitrogen applied at planting (first growth).

\begin{tabular}{lcccc}
\hline $\mathbf{N}$ at planting & \multicolumn{2}{c}{ Number } & $\begin{array}{c}\text { Dry mass } \\
(\mathbf{g} / \mathbf{p o t})\end{array}$ & Leaf/stem \\
\cline { 2 - 3 }$\left(\mathbf{m g ~ d m}^{-3}\right)$ & Tillers & Leaves & & \\
\hline 0 & $20.40^{\mathrm{a}}$ & $85.25^{\mathrm{b}}$ & $10.18^{\mathrm{b}}$ & $2.07^{\mathrm{a}}$ \\
15 & $20.30^{\mathrm{a}}$ & $96.87^{\mathrm{a}}$ & $13.13^{\mathrm{a}}$ & $2.07^{\mathrm{a}}$ \\
Means & 20.35 & 91.06 & 11.65 & 2.07 \\
CV $(\%)$ & 13.92 & 7.01 & 8.45 & 13.13 \\
\hline
\end{tabular}

Means followed by different lowercase letters in the column differ by $F$ test $(P \leq 0.05)$ for each variable.

Table 2. Numbers of tillers and leaves of ruzi grass grown in soil from cultivation of soybean planting system as a function of nitrogen applied at planting and topdressing (second growth).

\begin{tabular}{|c|c|c|c|c|c|c|}
\hline \multirow{3}{*}{$\begin{array}{l}\mathrm{N} \text { at coverage }(\mathrm{mg} \\
\left.\mathrm{dm}^{-3}\right)\end{array}$} & \multicolumn{3}{|c|}{ Number of tillers } & \multicolumn{3}{|c|}{ Number of leaves } \\
\hline & \multicolumn{3}{|c|}{$\mathrm{N}$ at planting $\left(\mathrm{mg} \mathrm{dm}^{-3}\right)$} & \multicolumn{3}{|c|}{$\mathrm{N}$ at planting $\left(\mathrm{mg} \mathrm{dm}^{-3}\right)$} \\
\hline & 0 & 15 & Means & 0 & 15 & Means \\
\hline 0 & 29.50 & 45.00 & 37.25 & 63.25 & 104.25 & 104.25 \\
\hline 15 & 29.25 & 44.00 & 36.62 & 83.75 & 120.50 & 102.12 \\
\hline 30 & 36.75 & 52.25 & 44.50 & 129.75 & 156.00 & 142.87 \\
\hline 45 & 44.50 & 51.50 & 48.00 & 130.50 & 162.25 & 146.37 \\
\hline Means & $35.00^{\mathrm{B}}$ & $48.19^{A}$ & & $101.81^{\mathrm{B}}$ & $135.75^{\mathrm{A}}$ & \\
\hline \multicolumn{7}{|l|}{ F test } \\
\hline Linear effect & & & ** & & & ** \\
\hline Quadractic effect & & & ns & & & ns \\
\hline CV (\%) & \multicolumn{3}{|c|}{12.60} & & \multicolumn{2}{|c|}{9.28} \\
\hline
\end{tabular}

Means followed by different capital letters for each variable differ by the $F$ test $(P \leq 0.05) .{ }^{* *}, P \leq(0.01) .{ }^{\text {ns }}$, not significant $(P \geq 0.05)$.

the number of tillers per plant increased, in line with the findings of Langer (1963). This result occurred because during the second growth significant differences were observed between the $\mathrm{N}$ rates that were applied at planting of the grass, where the $\mathrm{N}$ dose of $15 \mathrm{mg} / \mathrm{dm}^{3}$ resulted in a greater production of tillers (Table 2).

In the second growth, there was no interaction between the $\mathrm{N}$ rates applied at planting and those applied as topdressing (Table 2). An isolated response was observed, but only for the $\mathrm{N}$ rates that were applied as topdressing, fitting a linear regression equation (Figure 1a).

In second growth there was an average two-fold increase in the number of tillers, indicating that during the initial growth period, the soil $\mathrm{N}$ was sufficient for growth of the grass. However, during the second growth, N supplementation was necessary to increase the number of tillers. These results demonstrated the need to properly manage $\mathrm{N}$ fertilization associated with the use of legumes in the system of crop rotation using soybean as the previous crop.

According to Garcez Neto et al. (2002) N influences the activation of dormant buds and accelerates the tissue flow in individual tillers, increasing the turnover of leaves and tillers, which favors the production of forage. Since the flow of fabric appears to be influenced by the processes of absorption and partition recycling of nitrogen (Gastal et al, 1992). However, these results showed that the use of a legume alone in the system may not promote sufficient $\mathrm{N}$ accumulation for ruzi grass intercropped with second-crop corn, as also reported by Papendick et al. (1987).

\section{Number of ruzi grass leaves}

With respect to the number of leaves in the first growth, differences were observed between the $N$ rates at the planting, where the addition of $15 \mathrm{mg} \mathrm{dm}^{-3}$ promoted a $10 \%$ increase in the number of leaves (Table 1). The increase in the number of leaves in the first growth occurred because variation in the emergence of the leaves of the grasses fertilized with $\mathrm{N}$ are related to the direct effect that $\mathrm{N}$ has on the flow of cells within the meristematic region (Paiva et al., 2012).

In the second growth of the ruzi grass, the number of leaves exhibited differences between the $\mathrm{N}$ rates at planting, where supplying $15 \mathrm{mg} \mathrm{dm}^{-3}$ of $\mathrm{N}$ promoted a 

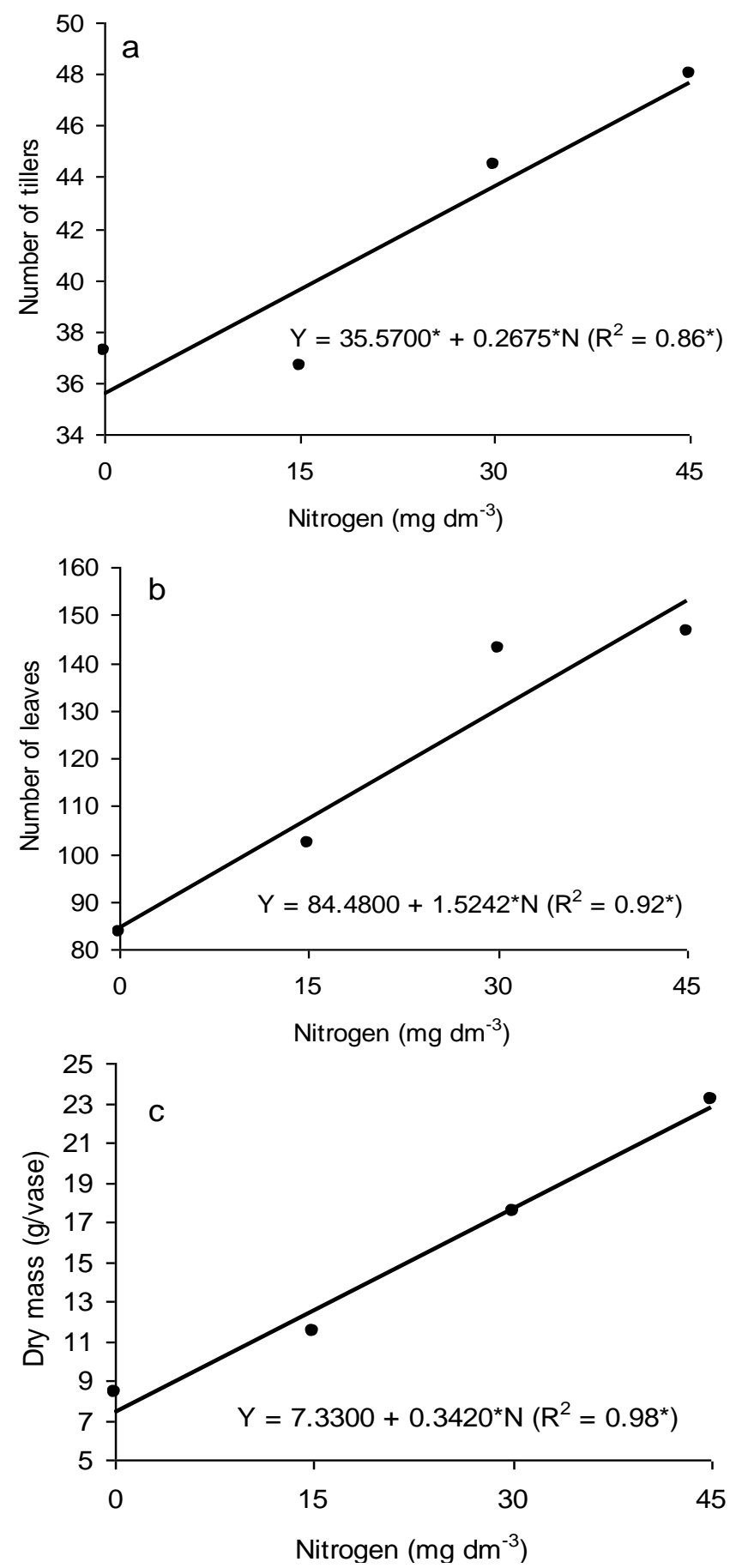

Figure 1. Production of tillers (a), leaves (b) and dry mass of shoots (c) in the second growth of ruzi grass a function of nitrogen rates.

$30 \%$ increase in the number of leaves (Table 2). However, for the number of leaves in the second growth of the grass, no interaction was observed between the $\mathrm{N}$ rates applied at planting and those as topdressing (Table 2). The number of leaves in the second growth responded linearly to the $\mathrm{N}$ topdressing rates and increased up to $80 \%$ as the $\mathrm{N}$ topdressing rates increased (Figure 1b).

This increase in the number of leaves as a function of the $\mathrm{N}$ concentration is related, according to Silveira et al. (2010), to the genetic characteristics of ruzi grass, because the number of leaves is genetically determined and is conditioned by environmental variation, with the most pronounced effects being related to temperature and $\mathrm{N}$ rate. It can therefore be inferred that the plants receiving $\mathrm{N}$ will reach their maximum number of leaves/tillers sooner than those that are not fertilized (Paiva et al., 2012).

\section{Shoot dry matter production of ruzi grass}

The shoot dry matter production in the first growth showed differences according to the $\mathrm{N}$ supply at planting. A supply of $15 \mathrm{mg} \mathrm{dm}^{-3} \mathrm{~N}$ at planting promoted a $30 \%$ increase in the shoot dry matter production, which may have been influenced by the greater number of leaves per pot, because there was no change in the number of tillers (Table 1).

The increase in the shoot dry matter production of the ruzi grass in the first growth can be because the first response of pastures to $\mathrm{N}$ fertilizer application is a rapid uptake of $\mathrm{N}$ and increased plant growth (Sun et al., 2008). Thus, the observed result in this work should be taken into account in soybean succession with consortium of second-crop corn with ruzi grass because showed that $\mathrm{N}$ from biological fixation of the soybean can be insufficient for adequate grass production (Sousa Nunes et al., 2011).

In the second growth of the ruzi grass, the shoot dry matter production showed no interaction between the $\mathrm{N}$ fertilizers applied at planting and the rates as topdressing (Table 3). However, differences were observed between the absence of $\mathrm{N}$ fertilization and the application of $15 \mathrm{mg}$ $\mathrm{dm}^{-3}$ at planting (Table 3). This result also coincides with the increase in number of tillers and leaves per pot, which contributed to the production of the forage mass.

During the second growth, a linear response of the $\mathrm{N}$ topdressing supply was observed (Figure 1c), with a $310 \%$ increase between the lowest and the highest $\mathrm{N}$ doses used for the topdressing. The response to the $\mathrm{N}$ rates observed during the second growth reaffirms the need to adjust the $\mathrm{N}$ rate and the application period to coincide with peak absorption by the grass and the improvement possible from use of the residual $\mathrm{N}$ from the previous crops (Islam and Garcia, 2012).

The linear increase in the shoot dry matter production in the second growth of the ruzi grass, as function of the $\mathrm{N}$ rates , can be explained by the fact that tropical forage needs $\mathrm{N}$ in large quantities as a result of the deposition of most of this nutrient during cell division. Furthermore, it is known that $\mathrm{N}$ fertilizer increases the production of dry mass because it accelerates the $\mathrm{N}$ flow to the tissues, 
Table 3. Production of dry mass of shoots and leaf/stem ratio of ruzi grass as a function of nitrogen applied at planting and topdressing (second growth).

\begin{tabular}{|c|c|c|c|c|c|c|}
\hline \multirow{3}{*}{$\begin{array}{l}\text { N at coverage } \\
\left(\mathrm{mg} \mathrm{dm}^{-3}\right)\end{array}$} & \multicolumn{3}{|c|}{ Dry mass } & \multicolumn{3}{|c|}{ Leaf/Stem } \\
\hline & \multicolumn{3}{|c|}{$\mathrm{N}$ at planting $\left(\mathrm{mg} \mathrm{dm}^{-3}\right)$} & \multicolumn{3}{|c|}{$\mathrm{N}$ at planting $\left(\mathrm{mg} \mathrm{dm}^{-3}\right)$} \\
\hline & 0 & 15 & Means & 0 & 15 & Means \\
\hline 0 & 7.68 & 8.43 & 8.06 & 0.97 & 1.05 & 1.01 \\
\hline 15 & 11.15 & 11.70 & 11.46 & 1.11 & 1.10 & 1.11 \\
\hline 30 & 16.66 & 18.36 & 17.51 & 1.10 & 1.07 & 1.08 \\
\hline 45 & 22.50 & 23.75 & 23.13 & 1.09 & 1.04 & 1.07 \\
\hline Means & $14.50^{\mathrm{B}}$ & $15.56^{\mathrm{A}}$ & & 1.07 & 1.07 & \\
\hline \multicolumn{7}{|l|}{$\mathrm{F}$ test } \\
\hline Linear effect & & & ** & & & ns \\
\hline Quadractic effect & & & ns & & & ns \\
\hline $\mathrm{CV}(\%)$ & \multicolumn{3}{|c|}{8.77} & & \multicolumn{2}{|c|}{10.09} \\
\hline
\end{tabular}

Means followed by different capital letters for each variable differ by the $F$ test $(P \leq 0.05) .{ }^{* *}, P \leq(0.01) .{ }^{\text {ns }}$, not significant $(P \geq 0.05)$.

increases the length of the leaves and increases the emergence and development of tillers. These factors are all positively correlated with forage production (Freitas et al., 2012).

The highest shoot dry matter production was observed in the final grass growth period, a result that may be related to the greater accumulation of non-structural carbohydrates that are mobilized from the roots and bases of the stems and transported to the shoots during the regrowth of the grass after the first cutting and to an increase in the number of tillers and leaves (Gomide, 1973; Botrel et al., 1990).

\section{Leaf/stem ratio of ruzi grass}

The leaf/stem ratio in the first growth of the ruzi grass did not exhibit differences between the absence of fertilization and the application of $15 \mathrm{mg} \mathrm{dm}^{-3}$ of $\mathrm{N}$ at planting (Table 1). The lack of differences in leaf/stem ratio is caused by acceleration in the growth rate with response in terms of forage accumulation, characterized by the proportional increase of leaves and stems in the forage mass (Pereira et al., 2010)

For the second growth, the $F$ test revealed no interaction between the $\mathrm{N}$ rates applied at planting and those as topdressing. Although no significance at $\mathrm{N}$ rates, there was 1.9-fold reduction in the relationship for the $\mathrm{N}$ rates applied at planting with the growth second. Additionally, the leaf/stem ratio in the second growth, of $1: 1$, is considered critical. These results demonstrate that nitrogen applications should be systematically evaluated (Sun et al., 2008).

\section{Conclusions}

The $\mathrm{N}$ rate of $15 \mathrm{mg} \mathrm{dm}^{-3}$ applied at planting the ruzi grass promoted an increase in the numbers of leaves and shoot dry matter production in the first and second growths. During the second growth, $N$ doses (15, 30 and $45 \mathrm{mg} \mathrm{dm}^{-3}$ ) applied as topdressing increased the number of leaves and the shoot dry matter production. The available $\mathrm{N}$ from the previous crop (soybean) was sufficient for the initial tillering of the ruzi grass, but the number of tillers in the second growth indicated that when $\mathrm{N}$ is deficient, the development of tillers is inhibited.

This study showed that the correct management of $\mathrm{N}$ fertilization is necessary for ruzi grass when grown after a previous crop (soybean in this case).

\section{ACKNOWLEDGEMENT}

We thank the Fundação de Amparo à Pesquisa do Estado de São Paulo - FAPESP for financial support.

\section{REFERENCES}

Batista K, Duarte AP, Ceccon G, De Maria IC, Cantarella H (2011). Dry matter and nutrient accumulation in forage plants intercropped with off-season maize as a function of nitrogen fertilization. Pesq. Agropec. Bras. 46:1154-1160.

Bland BF (1968). Nitrogen contribution from the soil for herbage growth. Plant Soil 28:217-225

Botrel MA, Alvin MJ, Martins CE (1990). Nitrogen application to Brachiaria cultivars. 2. Effect upon crude protein and nutrient content. Pasturas Trop. 12:7-10.

Cao L-H, Liu H-M, Zhao SW (2012). Relationship between carbon and nitrogen in degraded alpine meadow soil. Afr. J. Agric. Res. 7:39453951.

Cook BG, Pengelly BC, Brown SD, Donnelly JL, Eagles DA, Franco MA, Hanson J, Mullen BF, Partridge IJ, Peters M, Schultze-Kraft R 2005). Tropical Forages: an interactive selection tool, [CD-ROM]. CSIRO, DPI\&F(QId), CIAT and ILRI, Brisbane, AU.

Freitas FP, Fonseca DM, Braz TGS, Martuscello JA, Santos MER (2012). Forage yield and nutritive value of Tanzania grass under nitrogen supplies and plant densities. Rev Bras Zootecn 41:864-872.

Garcez Neto AF, Nascimento Junior D, Regazzi AJ, Fonseca DM, 
Mosquim PR, Gobbi KF (2002). Respostas morfogênicas e estruturais de Panicum maximum cv. Mombaça sob diferentes níveis de adubação nitrogenada e alturas de corte. Rev Bras Zootecn. 31:1890-1900.

Gastal F, Bélanger G, Herls PO (1992). The effects of nitrogen and the growing season on photosynthesis of fieldgrown tall fescue canopies. Ann. Bot-London 72:401-408.

Gomide JA (1973). Fisiologia e manejo de plantas forrageiras. Rev Bras Zootecn 2:17-26.

Halvorson AD, Reule CA, Follett RF (1999). Nitrogen Fertilization Effects on Soil Carbon and Nitrogen in a Dryland Cropping System. Soil Sci. Soc. Am. J. 63:912-917.

Hancock DW, Harris GH, Franks RW, Morgan, SP, Green, TW (2011). Soil and Fertilizer Management Considerations for Forage Systems in Georgia. Bulletin 1346. College of agricultural and Environmental Sciences, College of Family and Consumer Sciences, Georgia Univ.

Havlin JL, Beaton JD, Tisdale SL, Nelson WL (1999). Soil Fertility and Fertilizers: An Introduction to Nutrient Management. 6th ed. Prentice Hall, New Jersey, United States of America. P. 515.

Islam MR, Garcia SC (2012). Effects of sowing date and nitrogen fertilizer on forage yield, nitrogen- and water-use efficiency and nutritive value of an annual triple-crop complementary forage rotation. Grass Forage Sci. 67:96-110.

Langer RHM (1963). Tillering in herbage grass. Herbage Abstracts. 33:141-148.

Paiva AJ, Silva SC, Pereira LET, Guarda VD, Pereira PM, Caminha FO (2012). Structural characteristics of tiller age categories of continuously stocked marandu palisade grass swards fertilized with nitrogen. Rev Bras Zootecn 41:24-29.

Papendick RI, Lloyd E, Power JF (1987). Alternative production systems to reduce nitrates in ground water. Am. J. Altern. Agric. 2:1924.
Pereira LET, Paiva AJ, Da Silva SC, Caminha FO, Guarda VDA, Pereira PM (2010). Sward structure of marandu palisadegrass subjected to continuous stocking and nitrogen-induced rhythms of growth. Sci. Agric. 67:531-539.

Sarunaite L, Kadziuliene Z, Kadziulis L (2006). The effect of legumes on the accumulation of nitrogen in herbage yield on succeeding spring wheat. In: J.J. Lloveras, A. González- Rodríguez, O. Vázquez-Yañez, J. Piñeiro, O. Santamaría, L. Olea, M.J. Poblaciones, editors, Sustainable grassland productivity. Proceedings of the 21st General Meeting of the European Grassland Federation, Badajoz, Spain, 3-6 April, 2006. Grassland Science in Europe, Badajoz, ES, pp. 387-389.

Silveira MCT, Nascimento Júnior D, Silva SC, Euclides VPB, Montagner DB, Sbrissia AF, Rodrigues CS, Sousa BML, Pena KS, Vilela HH (2010). Morphogenetic and structural comparative characterization of tropical forage grass cultivars under free growth. Sci. Agric. 67:136142.

Sousa Nunes R, Lopes AAC, Sousa DMG, Mendes IC (2011). Management systems and the carbon and nitrogen stocks of cerrado oxisol under soybean-maize succession. R. Bras. Ci. Solo 35:14071419.

Sun X, Luo N, Longhurst B, Luo J (2008). Fertiliser nitrogen and factors affecting pasture responses. Open Agric. J. 2:35-42.

Werner JC (1986). Adubação de pastagens. Instituto de Zootecnia, Nova Odessa-SP, Brazil, (IZ. Boletim Técnico, 18). P. 49. 